\title{
Effect of Heat Treatment and Gamma Irradiation on the Total Bacterial Count of Selected Millet Grains (Jowar, Bajra and Foxtail)
}

\author{
Praveen Kumar Dikkala*, T.V. Hymavathi, Pradeepa Roberts and M. Sujatha
}

Post Graduate and Research Centre,

Professor Jayashankar Telangana State Agricultural University, Hyderabad-500030, India

*Corresponding author

Keywords

Gamma irradiation,

Millet grains,

Total bacterial count

Article Info

Accepted:

15 January 2018

Available Online:

10 February 2018

\section{A B S T R A C T}

Heat treatment and irradiation are the two advanced and innovative processing technologies for the inactivation of microorganisms to ensure the safety by extending the shelf life of foods. Irradiation along with the heat treatment proved that synergistic effect in the reduction of bacterial spores.Fungal count during storage gradually decreased up to 60 days and increased again almost to a level of $0^{\text {th }}$ day to $90^{\text {th }}$ day. Irrespective of treatments and storage the least fungal count was observed in pearl millet followed by sorghum and foxtail millet. The effect of storage was observed on foxtail millet than sorghum and pearl millet. Thus the present study is demonstrated that heat treatment and irradiation were more effective in controlling the microbial load than heat treatment alone.

\section{Introduction}

Heat treatment and irradiation are the two advanced processing technologies are two innovative for inactivation of microorganisms to ensure the safety by extending the shelf life of foods (Koopmans and Duizer, 2004; Mahapatra et al., 2005). Heat treatment is used for extend the shelf-life in some cereal products by the inactivation of toxigenic molds. Irradiation followed by heating proved to be synergistic effect in the reduction of bacterial spores (Farkas, 2004). The Food and Agriculture Organization of the United Nations ( FAO)/ International Atomic Energy Agency (IAEA)/World Health Organization (WHO) announced that dosages of irradiation not more than $10 \mathrm{kGy}$ would not result in toxic effect in the case of meat and meat products. It is a non-thermal treatment used for food preservation because it eliminates insect eggs and invisible microorganisms, improving the hygienic quality and maintaining nutritional value of food. 
Ionizing radiation can improve quality of food by inactivating the anti-nutritional factors and inhibiting the allergenic compounds. Moreover, it is a quick treatment which requires minimal sample preparation. Doses below $10 \mathrm{kGy}$ give a $2-3 \log 10$ reduction in spore numbers and this is not sufficient to reduce the microorganisms completely (Patterson et al., 2006). Yeasts are more radiation resistant than molds and vegetative bacteria. So, they are important in the spoilage of irradiated meat products such as sausages stored at refrigeration (Patterson et $a l .$, 2006; Smith and Suresh, 2004).

Consumption poultry products are increasing day by day due to its beneficial health effects and its nutritional value (Chouliara et al., 2007). For convenience of the consumer poultry products are usually cut and deboned, and the bacteria on the skin and meat of the chicken are the main causes of contamination during the portioning, and skinning, processes (Alain and Stéphane, 2008). In addition to this in the poultry products the crosscontamination during slaughtering of poultry products can be contaminated even after slaughtering. The major bacteria that are present in poultry products are E. coli, Salmonella spp. Listeria monocytogenes, and Campylobacter jejuni (Anang et al., 2007 and Hong et al., 2008).

\section{Materials and Methods}

Sorghum, foxtail millet and pearl millet are obtained from the local market in Hyderabad. Millet processing and heating were carried out in the millet processing center and the grains were irradiated at irradiation unit from the state agricultural university of Telangana state (PJTSAU). All the grains were stored in polythene bags until used under dry and cool conditions away from insects and pests. The grains were dehulled in an abrasive de huller (Gurunanak Engineering Co, Hyderabad) up to $17 \%$ removal of bran. In the present experiment electric rotary dryer was used which can be operated continuously for large quantity of grain.

\section{Grain treatment}

High moisture content in the grains is one of the main factors for spoilage. The moisture content can be reduced by the application of heat treatment. The whole and dehulled grains of $5 \mathrm{~kg}$ were exposed to heat treatment at a temperature of $150-170^{\circ} \mathrm{C}$ for $1.5 \mathrm{~min}$ at 300 rpm. Irradiation is one of the processing technologies currently available for the inactivation of microorganisms, and it has proven successful in ensuring the safety and extending the shelf life of foods (Mahapatra et al., 2005). The millet grains were irradiated by using cobalt60 gamma sources. Two different dosages $1.0 \mathrm{kGy}$ and $2.5 \mathrm{kGy}$ were used and the grains of 500 grams were packed in polythene pouches and exposed to the irradiation.

\section{Estimation of total fungal count}

The sample was agitated for 15 minutes in a vortex and serial dilutions of sample suspensions were prepared. Serial dilutions prepared for fungi are $0.1 \mathrm{ml}$ of respective dilutions were spread on sterilized petri plates containing potato dextrose agar and they were incubated at room temperatures $\left(28^{\circ} \mathrm{C} \pm 2{ }^{0} \mathrm{C}\right)$ for $24-72$ hours and $25^{\circ} \mathrm{C}$ respectively (Aneja, 2003).

Two replicates were maintained for each dilution. Serial dilutions used for viable plate count for fungi are in between $10^{-3}$ to $10^{-5}$.

\section{Storage studies and study design}

All the heat treated and irradiated grains with a control sample of $500 \mathrm{~g}$ were stored for 30 , 60, 90 days in HDPE pouches at $34^{\circ} \mathrm{C}$ to $36^{\circ} \mathrm{C}$ of temperature and $23 \%$ of humidity. The total fungal count were estimated at the 
end of $30^{\text {th }}$ day, $60^{\text {th }}$ day and $90^{\text {th }}$ day. The study was conducted using $3 \times 8 \times 4$ factorial design, which means 3 types of grains, 8 types of treatments and 4 levels of storage were used for the study.

\section{Statistical analysis of data}

All the results were statistically analyzed using STAT GRAPHICS centurion version 17.1.11. Multifactor ANOVA technique was used to test to find out the significant effect of treatments on total fungal count of the millet grains (Snedecor and Cochran, 1983). Comparison and significant difference between samples were found by conducting multiple range tests using Fisher's least significant difference (LSD).

\section{Results and Discussion}

The treatment mean was found to be $61.212 \times$ $10^{-4} \mathrm{CFUg}^{-1}$. There is no significant difference in between whole grains without any treatment (WC) and dehulled grains without treatment (DC) $(\mathrm{p}>0.05)$.Total fungal count on whole control grain is $133.5 \times 10^{-4} \mathrm{CFUg}^{-1}$, heat treatment reduced the fungal count by $43.75 \times 10^{-4} \mathrm{CFUg}^{-1}$ (32.77 percent, $\mathrm{p}<0.01$ ). A higher reductions of $113.42 \times 10^{-4} \mathrm{CFUg}^{-1}$ and $120.92 \times 10^{-4} \mathrm{CFUg}^{-1}$ (90.56 percent, $\mathrm{p}<0.01)$ were observed when heat treatment combined with irradiation at $1.0 \mathrm{kGy}$ and 2.5 $\mathrm{kGy}$ respectively in whole grains. Irradiation dosage at $2.5 \mathrm{kGy}$ is more effective than all other treatments. Effectiveness of gamma irradiation in reducing the development of fungi was studied by Mahmud et al. (2015). Prior to irradiation, the fungi formation was found to be $5.3 \times 10^{4} \mathrm{CFU} / \mathrm{g}$, where as it was decreased to $2.1 \times 10^{4}, 2.1 \times 10^{4}, 4 \times 10^{2,} 3 \times$ $10^{2}$ and $3 \times 10 \mathrm{CFU} / \mathrm{g}$ after radiation treatment at doses of $0.25,0.50,0.75,1.0$, and $2.0 \mathrm{kGy}$, respectively. Reduction in the fungal incidence rate in millet grains after radiation might be due to high sensitivity of the fungus and mold to gamma radiation, since the radiation process causes direct and indirect damage to the DNA (Refai et al., 1996; McNamara et al., 2003).

The total fungal count on dehulled control grains (DC) is $140.29 \times 10^{-4} \mathrm{CFUg}^{-1}$ of TFC. Heat treatment reduced the count significantly by $67.67 \times 10^{-4} \mathrm{CFUg}^{-1} \quad(48.23$ percent, $\mathrm{p}<0.05)$. Significant reductions in the fungal count were observed with heat treatment, 1.0 and 2.5 KGy of irradiation treatments $(\mathrm{p}<0.01)$. However there is no significant difference is observed among the DHEI 2.5, WHEI 2.5, DHEI 1.0 and WHEI 1.0 ( $\mathrm{p}>0.05)$. Maity et al., (2004) studied on the application of gamma irradiation up to $6 \mathrm{kGy}$ $(0.12 \mathrm{kGy} / \mathrm{h})$ in rice (Oryza sativa) and pulse (Cicer arietinum) and they concluded that significant reduction in the fungal growth on these grains was noted at 1-2 kGy, while complete inhibition of the contaminating fungi was observed above $4 \mathrm{kGy}$. The fungal growth and their population on gamma treated rice was found to decreased significantly with increasing irradiation dose and storage time.

Irradiation at a dose of $5 \mathrm{kGy}$ inactivated the fumonisin B1 by $96.6 \%, 87.1 \%$ and $100 \%$ on wheat, maize and barley respectively (Aziz et al., 2006). Similar trends were reported by Basson and Villiers (1992) in their studies with gamma irradiation. Ramakrishna et al. (1991) reported that Fusarium spp decreased significantly in barley at a dose of $4 \mathrm{kGy}$ irradiation dose. Similar studies were done by Balasubrahmanyam (2006) on Fusarium infected barley and the irradiation at 6 to 8 kGy irradiation maybe effective in reducing Fusarium I in barley and DON in barley malt with minimal effects on the quality of malt. Fungal growth and aflatoxin production was significantly higher in the germ than in other kernel tissues (Keller et al., 1994 and Brown et al., 1995). 
The studies on storage revealed that the initial fungal count was $77.970 \times 10^{-4} \mathrm{CFUg}^{-1}$ was increased to $1.82 \times 10^{-4} \mathrm{CFUg}^{-1}$ (2.33 percent) at $30^{\text {th }}$ day, however there was no statistically significant difference even at $95 \%$. Further increase in the storage time decreased the fungal count significantly by 28.34 percent, 59.98 percent on $60^{\text {th }}$ and $90^{\text {th }}$ day respectively. The fungal growth and their population on gamma treated rice was found to be decreased significantly $(p<0.05)$ with the increasing irradiation dose and storage time. Immediately after irradiation, the depletion of fungal growth on rice was noticed at $2 \mathrm{kGy}$, whereas total inhibition was noticed at $3 \mathrm{kGy}$ after one and half month (Maity et al., 2004).The interaction effect of treatment and grain revealed that significant variation among the grains and treatments. Maximum effect of treatment was observed in foxtail millet and a minimum effect in pearl millet. The fungal count was higher in DC than that of WC and no significant difference was found between DHE and WHE. Heat and irradiation treatment was more effective than heat treatment alone. With increasing dose from 1.0 to $2.5 \mathrm{KGy}$ reduced the fungal count by 98.46 and 99.68 percent in whole and dehulled grains respectively.
In case of sorghum unlike foxtail millet both dehulled and whole grains does not have similar fungal count. Heat treatment was effective in controlling fungal count by 94.8 and 66.36 percent in whole and dehulled grains respectively. Irradiation in combination with heat treatment controlled 68.35, 79.03 and 75.26, 90.91 percent and in whole and dehulled grains at 1.0 and $2.5 \mathrm{KGy}$ doses respectively. With respect to pearl millet lower fungal count in DC is lower than that of WC like in foxtail millet. The treatments controlled the fungal count by $66.38,63.13$ and 92.30 percent with heat and combination of irradiation at 1.0 and $2.5 \mathrm{KGy}$ respectively in dehulled grains. In whole grains 27.5, 70.49 and 72.69 percent reductions in fungal count was observed in heat and combination of irradiation at 1.0 and $2.5 \mathrm{KGy}$ respectively. In conclusion it can be said that heat in combination with irradiation at $2.5 \mathrm{kGy}$ was found to be more effective in controlling fungal count except in foxtail millet. The viable counts of Fusarium decreased significantly with increase in the irradiation dose levels. The lethal dose was $4.0 \mathrm{kGy}$ in barley and $6.0 \mathrm{kGy}$ in wheat and maize (Gharib and Aziz, 1995).

Table.1

\begin{tabular}{|l|l|l|l|}
\hline Sno & Treatments (8) & Grains (3) & $\begin{array}{l}\text { Storage } \\
\text { period(4) }\end{array}$ \\
\hline 1 & Control -Whole grain (WC) & Sorghum & 0 Day \\
\hline 2 & Control- Dehulled grain (DC) & Pearl Millet & $30^{\text {th }}$ day \\
\hline 3 & Heat treated -Whole grain(WHE) & FoxtailMillet & $60^{\text {th }}$ day \\
\hline 4 & Heat treated -Dehulled grain (DHE) & & $90^{\text {th }}$ day \\
\hline 5 & Heat and 1.0KGy Irradiated Whole grain (WHEI 1.0) & & \\
\hline 6 & Heat and 2.5KGy Irradiated - Whole grain (WHEI 2.5) & & \\
\hline 7 & Heat and 1.0KGy Irradiated -Dehulled grain (DHEI 1.0) & & \\
\hline 8 & Heat and 2.5KGy Irradiated - Dehulled grain (DHEI 2.5) & & \\
\hline
\end{tabular}




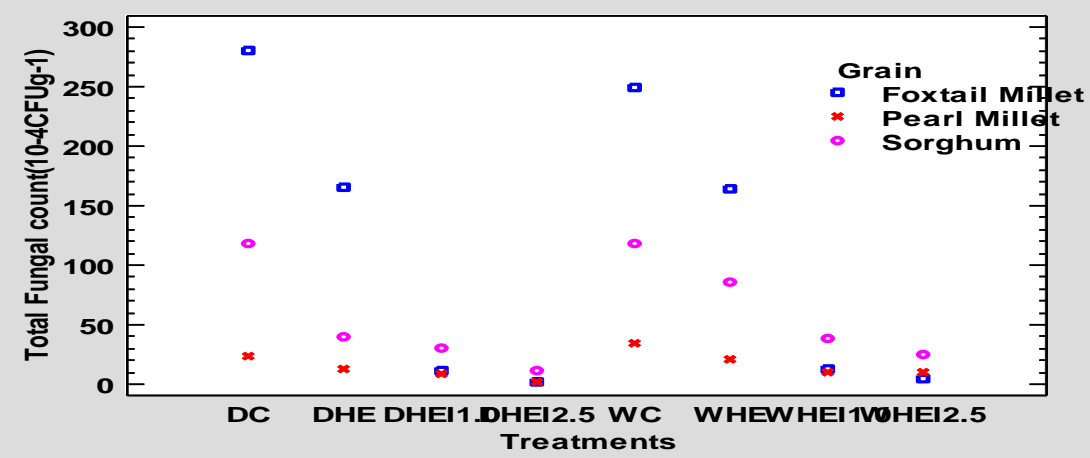

A) Interaction of Treatment and Grain

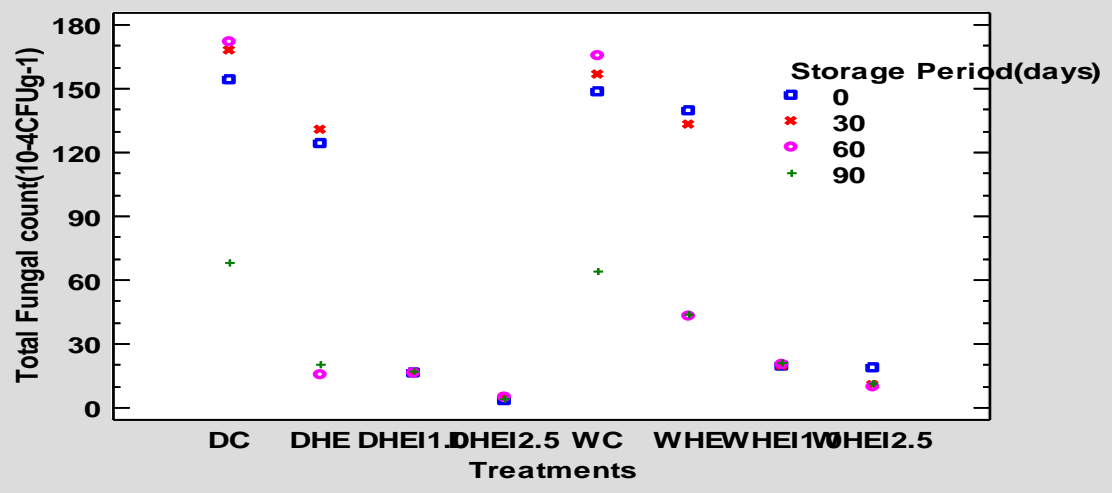

B) Interaction of Treatment and Storage

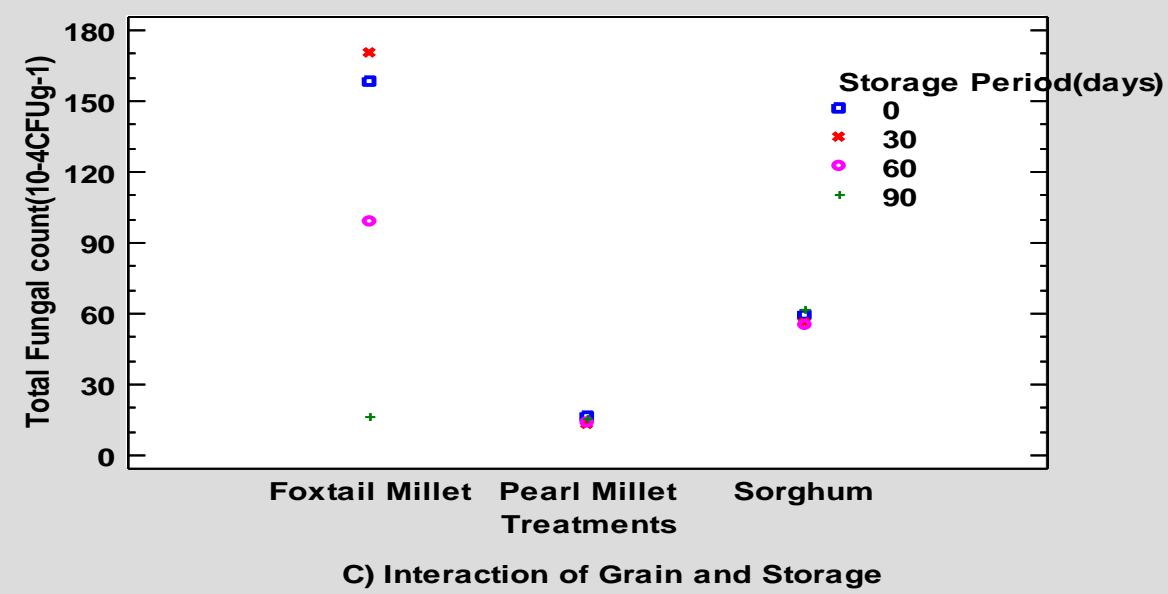


Mukisa et al., (2012) studied on irradiation dose at $10 \mathrm{kGy}$ and concluded that the microbial count was reduced about $3 \mathrm{log}$ cycles in malted flour in sorghum. Gupta et al. (2009) studied that gamma irradiation on T. foenumgraecum at a dose of $2.5 \mathrm{kGy}$ resulted in 2 log reduction of total viable count whereas no microbial load was observed at $5 \mathrm{kGy}$ irradiation dose. Similarly, Sarojet al. (2007) studied that aerobic plate counts on grains such as Phaseolus aureus, Phaseolusa conitifolius, Picer arietinum and Pisum sativum were 2.0 to $2.6 \mathrm{log} \mathrm{CFU} / \mathrm{g}$, which were reduced to 0.9 to $1.2 \log \mathrm{CFU} / \mathrm{g}$ on treatment at $2 \mathrm{kGy}$ radiation dose. The interaction effect of treatment and storage on fungal count was highest in foxtail millet followed by the sorghum and pearl millet. There was a marginal increase in the fungal count from 0 to 30 days in foxtail millet and a decrease in pearl millet and sorghum at 30 days of storage. Again a decrease was observed in fungal count from 30 to 60 days. At 90 days of storage an increase was observed in the fungal count of the grains except in foxtail millet.

The interaction effect of storage and grain revealed that higher effect of storage was observed in foxtail millet than the other two grains. In foxtail millet there was an increase in fungal count from 0 to 30 days and then decrease was observed from 37.68 and 89.50 percent at 60 and 90 days respectively. In pearl millet there was a decline in fungal count by $18.65,17.84$ and 6.01 percent at 30 , 60 and 90days respectively. In case of sorghum reduction was observed at 30 and 60 days by 5.28 and 7.17 percent respectively and slight increase (3.89 percent) at 90 days of storage.

In conclusion, both heat treatment and irradiation combined treatments significantly controlled the total fungal count, however significantly higher control was achieved with later. Fungal count during storage gradually decreased up to 60 days and increased again almost to a level of 0 day to 90 days. Irrespective of treatments and storage the least fungal count was found in pearl millet followed by sorghum and foxtail millet. Maximum grain and treatment interaction effect was observed in foxtail millet and a minimum in pearl millet. A higher effect of storage was observed on foxtail millet than other two grains. Thus the present study is demonstrated that heat and irradiation combined effect was more effective in controlling microbial load than heat treatment alone. The literature clearly showed that there are no adverse effects on the millets which are treated with irradiation at a dosage of 2.5 kGy.

\section{References}

Alain, K. and Stephane, P.2008. Effect of superheated steam on the inactivation of Listeria innocua surface-inoculated onto chicken skin. Journal of food engineering, 87(2), 162-171.

Anang, D. M., Rusul, G., Bakar, J and Ling, F. H.2007. Effects of lactic acid and lauricidin on the survival of Listeria monocytogenes, Salmonella enteritidis and Escherichia coil $\mathrm{O} 157: \mathrm{H7}$ in chicken breast stored at $4^{\circ} \mathrm{C}$. Food control, 18(8): 961-969

Aneja., K. R. 2003. Experiments in Microbiology, Plant Pathology and Biotechnology. New Age International publications. New Delhi. Pp. 69-71.

Aziz, N.H., Souzan, R.M and Azza, A.S.2006. Effect of gamma irradiation on the occurrence of pathogenic microorganisms and nutritive value of four principal cereal grains. Journal of Applied Radiation and Isotopes. 64: 1555-1562.

Balasubrahmanyam, K., Charlene. E. WolfHall and Paul Schwarz. 2006. Effect of 
electron-beam irradiation on the safety and quality of Fusarium-infected malting barley. Journal of Food Microbiology. 110: 224-231.

Basson, A.B.K and De Villiers, O.T. 1992. Effect of irradiation on quality characteristics of clipper barley and malt. Journal of American society of Brewing chemists. 50: 106-109.

Brown, R. L., Cleveland, T. E., Payne, G. A., Woloshuk, C. P., Campbell, K. W., and White, D. G. 1995. Determination of resistance to aflatoxin production in maize kernels and detection of fungal colonization using an Aspergillus flavus transformant expressing Escherichia coli $\beta$-glucuronidase. Journal of Phytopathology. 85:983-989.

Chouliara E., Karatapanis A., Savvaidis I.N., Kontominas M.G. 2007. Combined effect of oregano essential oil and modified atmosphere packaging on shelf-life extension of fresh chicken breast meat, stored at $4{ }^{\circ} \mathrm{C}$. Food Microbiology. 24: 607-617.

Farkas, J. 2004. Charged particle and photon interactions with matter. Journal of Food Irradiation :785-812.

Gharib, O.H and Aziz, N.H. 1995. Effect of gamma irradiation and storage periods on the survival of toxigenic microorganisms and khapra beetle Trogoderma granarium in crushed corn. Journal of Egyptian society of Toxicology.15: 23-28.

Gupta,P.C., Bajpai, V., Mishra,V., Saxena, R.K and Singh, S. 2009. Effect of gamma irradiation on microbial load, aflatoxins and phytochemicals present in Trigonellafoenum-graecum. Journal of microbiology and Biotechnology. 25:2267-2271.

Hong, Y. H., Ku, K. J., Kim, M. K., Won, M. S., Chung, K. S., and Song, K. B.2008. Survival of Escherichia coli O157:H7 and Salmonella typhimurium inoculated on chicken by aqueous chlorine dioxide treatment. Journal of Microbiology and Biotechnology, 18(4): 742-745.

Koopmans, M and Duizer, E. 2004. Food borne viruses: an emerging problem. Journal of Food Microbiology. 90 2324.

Keller, N. P., Butchko, R. A. E., Sarr, B and Phillips, T. D.1994. A visual pattern of mycotoxin production in maize kernels by Aspergillus spp. Journal of Phytopathology. 84: 483-488.

Maity, J.P., Chakraborthy, A., Saha,A., Santra,S.C. and Chanda, S. 2004. Radiation induced effects on some common storage edible seeds in Indian fested with surface microflora. Journal of Radiation Physics and Chemistry. 71: 1065-1072.

Mahapatra, A.K., Muthukumarappan and Julson, J.L. 2005. Applications of ozone, bacteriocins and irradiation in food processing. Journal of Food Science Nutrition 45:447-461.

Mahmoud, N.S., Awad, S.H.M., Fahmi, A. O., Elmamoun, $\mathrm{K}$ and Hassan, A. B. 2015. Effect of gamma radiation processing on fungal growth and quality characteristics of millet grains. Journal of Food Science and Nutrition. 3: 295.

McNamara, N. P., Black, H. I. J., Beresford, N. A and Parekh, N. R.2003. Effects of acute gamma irradiation on chemical, physical and biological properties of soils. Application of Soil Ecology. 24:117-132.

Mukisa, I.M., Charles Muyanja, Yusuf Byenkya Byaruhanga and Judith. A. Narvhus. 2011. Gamma irradiation of sorghum flour: Effects on microbial inactivation, amylase activity, fermentability, viscosity and starch granule structure. Journal of Radiation physics and chemistry. 81(3):345 - 351.

Patterson, M., Connoly, M. and Darby, D. 2006. Effect of gamma irradiation on 
microbiological quality of seeds and seeds sprouts. Journal of International Atomic Energy. 536.

Ramakrishna, N., Lacey, J and Smith, J.E. 1991. Effect of surface sterilization, fumigation and gamma irradiation on the microflora and germination of barley seeds. International Journal of Food Microbiology. 13: 47-54.

Refai, M. K., Aziz, N. H., Far, F.E and Hassan, A. A.1996. Detection of ochratoxin produced by A. ochraceus in feedstuffs and its control by gamma radiation. Application of Radiation Isotopes. 47:617-621

Saroj, S.D., Hajare, S., Shashidhar, R.,
Dhokane, V., Sharma, A. and Bandekar, J.R. 2007. Radiation processing for elimination of Salmonella typhimurium from inoculated seeds used for sprout making in India and effect of irradiation on germination of seeds. Journal of Food science and technology. 70:19611965.

Smith, J.S and Suresh, P. 2004. Irradiation and food safety, Food technology. Journal of Irradiation and Food safety. 58 (11):48-55.

Snedecor George, W and Cochran William, G.1989. Statistical methods. Eighth Edition, Lowa state University press.

\section{How to cite this article:}

Praveen Kumar Dikkala, T.V. Hymavathi, Pradeepa Roberts and Sujatha, M. 2018. Effect of Heat Treatment and Gamma Irradiation on the Total Bacterial Count of Selected Millet Grains (Jowar, Bajra and Foxtail). Int.J.Curr.Microbiol.App.Sci. 7(02): 1293-1300. doi: https://doi.org/10.20546/ijcmas.2018.702.158 